\title{
The Implementation of Land Consolidation Policy for Housing Development
}

\author{
Nany Yuliastuti*, Ragil Haryanto \\ Urban and Regional Planning Department, Diponegoro University, Indonesia
}

\begin{abstract}
Housing and settlements have long been one of the problems faced in urban areas. The high rate of population growth and the rate of urbanization has led to high demand for housing and settlements. However, in many cases in urban areas, the available land is minimal, causing the emergence of pockets of slums. One method that can be done to solve the problem of slums is to carry out land consolidation. Therefore, this study aims to determine the criteria that influence the implementation of land consolidation. This research is a descriptive study with a literature analysis method. The results obtained are factors that influence the implementation of land consolidation are location and community factors.
\end{abstract}

Keywords: Land-Consolidation, Policy Planning, Housing Development.

\section{Introduction}

Land consolidation has often been done, but this experience needs to be taken into account more, primarily when it is associated with land for low-income people. This article will explain to what extent this land consolidation program has been carried out in several cities in Indonesia. Through the experience of several cities that have carried out this program, it is hoped that the concept of land consolidation can be implemented in the future. This research will be anonymous through a comparative study of several cities that have achieved land consolidation through descriptive analysis. The indicators of the success of a land consolidation program in Indonesia will be obtained.

Housing as a form of "right of residence" is a fundamental right of every citizen, so everyone has the right to access housing, including in urban areas. Even though the construction of public housing needs to reach all levels of society, it needs to pay attention to its suitability with the regional spatial plan to prevent the development of an uncontrolled city (urban sprawl). The construction of affordable housing includes several interrelated parts, ranging from land acquisition to financing, to the provision of public housing. Housing and settlements are problems that have long been faced in urban areas to create decent housing for the community [1]. On the other hand, development activities in Indonesia are not only intense in the formal sector but also in the informal sector because

* Corresponding author: nanyyuliastuti@lecturer.undip.ac.id 
the informal sector has the potential to be developed, resulting in an increase in urbanization in urban areas. The increasing phenomenon of urbanization causes an increase in high housing needs [2]

Slum settlement arises as a result of settlement space that is less integrated, directed, and planned. Less attention to the completeness of infrastructure facilities and arrangements, so it tends to experience degradation or degradation of environmental quality that causes the area to become slums [3]. Factors that encourage the existence of slums in urban areas include high population growth rates, limited open space, low community income, limited land for development, inadequate facilities and infrastructure, and little awareness of the community in maintaining the surrounding environment [4].

One step that can be taken to deal with the problem of slums is through land restructuring or land consolidation [5]. Through land consolidation, which is solving the problem of developing land for life, is expected to create land-use optimally by including the nature of the non-governmental community [6]. This study aims to determine what are the factors that influence the implementation of land consolidation.

\section{Literature review}

Land consolidation is a policy of restructuring the use, ownership, control, and use of land and space by the spatial plan. It is divided based on the function and designation of the area to improve the quality of the environment and preserve natural resources for the public interest by involving the active participation of the community [7]. According to Coelho [8], land consolidation is a solution for solving spatial problems through concentrating plots by eliminating land fragmentation.

Mulyanti [9] states that the objectives of land consolidation consist of three things, namely: a. The achievement of optimal land use; b. Encourage the community to participate in joint development; c. Increase the efficiency of land use and explain the legal certainty of landowners by structuring land tenure and use. Refers to participatory processes and collective action because landowners are empowered to make decisions about planning, service, and rebuilding [10].

One of the efforts made in optimizing land use by land consolidation is the arrangement of housing areas. Land consolidation is considered necessary in housing development policies because land consolidation has the following unique characteristics [11]: a. Its implementation procedures respect land rights and uphold the justice aspect by involving the active participation of landowners; b. Landowners should not be evicted from their environment; c. Benefits derived from the increase in land value-added and implementation costs are distributed relatively; $d$. Land tenure management is carried out at the same time as land use management and land consolidation certification; e. Implementation costs are sought from landowners so that they do not rely solely on minimal government fees; $f$. Land use is arranged efficiently and optimally by referencing the Regional Spatial Plan and providing land for the facilities and infrastructure needed to support local government policies.

\section{Methodology}

In conducting this research, a descriptive research method is used, in which the assessment process requires vivid and detailed exposure to the research object. This analysis qualitative descriptive analysis by the research objectives, to find the factors that influence land consolidation. The qualitative descriptive analysis method used is a literature analysis of various land consolidation practices as a lesson learns in housing development. This 
research is the first step and will be continued for the next applied research related to land consolidation in urban slums.

\section{Result and discussion}

\subsection{Analysis of Community Willingness to Receive Urban Land Consolidation Program in Jakarta}

This article discusses the availability of communities to receive urban land consolidation programs [12]. The study was conducted at RW (Neighborshood Association) 014, Kebon Melati, Central Jakarta. The selection of research sites is based on the following criteria.

1. Compliance with the Regional Spatial Plan

2. Initial community interest

3. Support from stakeholders

4. Accessibility

5. Number of participants, number of plots of land and area to be arranged

6. Land status

7. State of topography

Land consolidation carried out in RW 014 Kebon Melati; Central Jakarta is a consolidation of land from horizontal to vertical in the form of plans for the construction of flats. Therefore in terms of community acceptance or rejection is one of the main factors determining the implementation of land consolidation. Measuring the willingness to accept a land consolidation program will ensure the implementation of the land consolidation program. It is done through the measurement of variables and parameters (see Table 1).

Table 1. Variable and Parameter.

\begin{tabular}{|l|l|l|}
\hline \multicolumn{1}{|c|}{ Variable } & \multicolumn{1}{|c|}{ Source } & \multicolumn{1}{c|}{ Parameter } \\
\hline $\begin{array}{l}\text { Characteristics } \\
\text { of respondents }\end{array}$ & $\begin{array}{l}\text { Yeates and } \\
\text { Gurner } \\
(1980: 273)\end{array}$ & $\begin{array}{l}\text { Age, sex, type of work, marital status, respondent status in } \\
\text { the household, education, area of origin, number of family } \\
\text { members, income level. }\end{array}$ \\
\hline $\begin{array}{l}\text { Housing and } \\
\text { environmental } \\
\text { conditions }\end{array}$ & $\begin{array}{l}\text { Rapoport } \\
(1977: 129) \\
\text { Daldjoeni } \\
(1997: 80)\end{array}$ & $\begin{array}{l}\text { The data like the status of ownership, land ownership, land } \\
\text { area, building area, physical type of residential building, the } \\
\text { current standard of the physical construction, length of stay, } \\
\text { present condition of the building, number of rooms is needed } \\
\text { to identify the characteristics of the resident. Whether the } \\
\text { house is served by electricity, whether the home is served by } \\
\text { the PDAM, whether Telkom helps the house, is the house } \\
\text { used as a place of business, the availability of social facilities } \\
\text { / public facilities, the level of environmental cleanliness, } \\
\text { security, conditions of relations between residents, types of } \\
\text { roads. }\end{array}$ \\
\hline $\begin{array}{l}\text { Willingness to } \\
\text { accept urban } \\
\text { land } \\
\text { consolidation } \\
\text { program }\end{array}$ & $\begin{array}{l}\text { Potter (1982:23) } \\
\text { Teers (1985:50) } \\
\text { Dunhan } \\
(1994: 370)\end{array}$ & $\begin{array}{l}\text { Knowing/not knowing about the land consolidation program, } \\
\text { guarantee of not being evicted, the certainty of getting a } \\
\text { house or unit of flats, temporary relocation with funding by } \\
\text { the government, KTP participants get a Flat Right Ownership } \\
\text { Certificate, a reasonable relocation fee. }\end{array}$ \\
\hline
\end{tabular}

Source: [12]

Based on the analysis in article community willingness to receive urban land consolidation program, it was mentioned that the level of community willingness to accept 
urban land consolidation programs is 64\%. When compared with Law No. 1 of 2011 concerning. Housing and Settlement Areas, a minimum agreement of participants and land area is $60 \%$. The community's willingness to accept the urban land consolidation program meets the criteria.

\subsection{Land Consolidation by Mapping Participation in Kahayan Riverbank, Palangkaraya}

This study aims to examine the potential for the implementation of land consolidation based on mapping participation seen from a governance perspective [13]. Good governance can be seen from the principle of government and public relations. This study took the location of the survey in a slum area along the Kahayan River, Palangkaraya City. This location was chosen because it is included in the Palangkaraya Neighborhood Upgrading and Shelter Project (NUSP) program. The implementation of land consolidation based on participatory mapping is carried out in two stages, namely:

1. Land census, which includes information on land administration, settlement conditions, opinions related to settlement structuring programs and community socioeconomic characteristics,

2. FGD (Focus Group Discussion) involves representatives from the community to describe environmental problems and provide infrastructure development proposals for the problems encountered.

Based on the analysis, the Kahayan Riverbank settlement area is included in the category of slums that can be eliminated by the concept of land consolidation by rearranging land parcels and infrastructure development.

\subsection{Evaluation of Community Perception in Land Consolidation Process in Kurau Village, Central Bangka}

The research aims to evaluate the process of land consolidation in slums [5]. The study was conducted in a slum area on the Kurau riverbank, Central Bangka, where the revitalization of the slum area has been carried out using a land consolidation method in 2012. The selection research sites based on the potentials of the Kurau Village, located in a coastal area. Evaluation is done based on the process that has been done. The process is;

1. Scoping agreements (accessibility, comfort, and conditions of facilities and infrastructure)

2. Preparation of the master plan,

3. Socialization and deliberation,

4. Certificate and relocation/transfer of design to the field,

5. Government support.

Differentiate the analysis conducted, it was found that the process of land consolidation in the slums of Kurau Village has been successful. However, the land consolidation process not followed by the successful implementation where the reallocation and arrangement had stopped.

\subsection{Factors that Influence the Implementation of Land Consolidation}

Based on the articles discussed earlier with the study area taken different can be compared to several variables or factors in the implementation of land consolidation. These factors are location factors and community factors (see Table 2 ). 
Table 2. Comparison of factors.

\begin{tabular}{|c|c|c|}
\hline $\begin{array}{l}\text { Land Consolidation in } \\
\text { Housing Development }\end{array}$ & Location Factor & Community Factor \\
\hline $\begin{array}{l}\text { Community Willingness to } \\
\text { Receive Urban Land } \\
\text { Consolidation Program in } \\
\text { Jakarta }\end{array}$ & $\begin{array}{l}\square \text { Compliance with the } \\
\text { Regional Spatial Plan } \\
\square \text { Support from stakeholders } \\
\text { Housing and } \\
\square \text { environmental } \\
\text { conditions } \\
\square \text { Accessibility } \\
\square \text { Number of plots of land } \\
\text { and } \\
\quad \text { area to be arranged } \\
\square \quad \text { Land status } \\
\square \text { Topographical conditions }\end{array}$ & $\begin{array}{l}\text { Initial community interest } \\
\square \text { Characteristics of } \\
\text { respondents } \\
\square \text { Information about } \\
\text { willingness to accept an } \\
\text { urban land consolidation } \\
\text { program }\end{array}$ \\
\hline $\begin{array}{l}\text { Mapping Participation in } \\
\text { the } \\
\text { Kahayan Riverbank, } \\
\text { Palangkaraya }\end{array}$ & $\square$ Potential of location & $\begin{array}{l}\text { Scoping agreements by } \\
\text { community opinions } \\
\text { regarding accessibility, } \\
\text { comfortability condition of } \\
\text { facilities and infrastructure }\end{array}$ \\
\hline $\begin{array}{l}\text { Evaluation of the Process of } \\
\text { Land Consolidation Based } \\
\text { on } \\
\text { Community Perception, in } \\
\text { Kurau Village, Central } \\
\text { Bangka }\end{array}$ & $\begin{array}{l}\square \text { Land administration } \\
\square \text { Settlement environmental } \\
\text { conditions }\end{array}$ & $\begin{array}{l}\text { Socioeconomic } \\
\text { characteristics of the } \\
\text { community } \\
\square \text { Opinions related to } \\
\text { settlement structuring } \\
\text { programs } \\
\text { Community participation } \\
\square \text { in } \\
\text { describing development } \\
\text { problems and proposals }\end{array}$ \\
\hline
\end{tabular}

Source: Analysis, 2020

Based on the literature analysis, the implementation of land consolidation is strongly influenced by two factors, namely location and community factors. Location factors are factors related to an area's condition, while community factors are factors related to community characteristics and participation. The following factors influence the implementation of land consolidation (see Table 3). 
Table 3. The implementation of land consolidation.

\begin{tabular}{|c|c|}
\hline Loc & Community Factor \\
\hline $\begin{array}{l}\square \text { Compliance with the Regional } \\
\text { Spatial Plan } \\
\square \text { Support from stakeholders } \\
\square \text { Housing and environmental } \\
\text { conditions } \\
\square \text { Land administration } \\
\square \text { Topographical conditions }\end{array}$ & $\begin{array}{l}\square \text { Initial community interest } \\
\square \text { Characteristics of respondents } \\
\square \text { Socioeconomic characteristics of the } \\
\text { communit } \\
\mathrm{y} \\
\square \text { abou accep } \\
\text { urban land consolidation } \\
\text { program } \\
\text { Communit an to } \\
\square \text { y describing } \\
\text { development problems and } \\
\text { proposals }\end{array}$ \\
\hline
\end{tabular}

Source: Analysis, 2020

\section{Conclusion}

Slums arise due to a lack of planned planning and supervision, causing environmental degradation. The alleviation of slums can be overcome by one of the methods, land consolidation, or land restructuring. The purpose of land consolidation is to achieve optimal land use through optimization of productivity and land-use efficiency. Determining the factors that influence the implementation of land consolidation is obtained by literature analysis from case studies of slum areas in different locations, namely Jakarta, Palangkaraya, and Central Bangka.

Based on the literature analysis of the three case studies, it was found that the implementation of land consolidation in the eradication of slum areas was influenced by location and community factors. Location factors consist of several things, namely conformity with the Regional Spatial Plan, location supported by stakeholders, housing and environmental conditions, land administration, and topographical conditions. In contrast, community factors consist of initial interest, respondent characteristics, socioeconomic characteristics, information on the willingness to accept urban land consolidation programs, and community participation in describing problems and proposals for development. It is consistent with Sujarto [6] and Louwsma et al. [10], which states that the implementation of land consolidation is a participatory process involving communities as landowners develop land-use optimally. The community's willingness to participate in this program was the primary indicator; for this reason, the more intensive collaboration between community and governments is needed to accept this program.

\section{Acknowledgment}

The authors would like to thank the Department of Urban and Regional Planning, Engineering Faculty, Diponegoro University, and all who have helped this research. 


\section{References}

[1] S. Kim and P. G. Rowe, "Are master plans effective in limiting development in China's disaster-prone areas?," Landsc. Urban Plan., 111, 79-90 (2013).

[2] N. Yuliastuti and Y. Widiastomo, "Towards Better Social Housing Policy Based on Residents' Satisfaction: A Case Study at Sendangmulyo, Semarang, Indonesia," J. Sustain. Dev., 8, 2, 149 (2015).

[3] A. Hariyanto, "Strategi Penanganan Kawasan Kumuh Sebagai Upaya Menciptakan Lingkungan Perumahan dan Permukiman yang Sehat (Contoh Kasus: Kota Pangkalpinang)," J. Perenc. Wil. dan Kota UNISBA, 7, 2, 11- 37 (2007).

[4] B. Suud and P. Navitas, "Faktor-faktor Penyebab Kekumuhan Permukiman di Kelurahan Tanah Kalikedinding, Kecamatan Kenjeran, Surabaya," J. Tek. ITS, 4, 1, C33--C35 (2015).

[5] Y. Yurmansah and M. Mussadun, "Evaluasi Proses Konsolidasi Tanah Kawasan Permukiman Kumuh Bantaran Sungai Kurau Klaster 1 Desa Kurau Berdasarkan Persepsi Masyarakat,” J. Pembang. Wil. KOTA, 12, 1, 98-111 (2016).

[6] D. Sujarto, "Konsolidasi Lahan Perkotaan Sebagai Suatu Model Pengelolaan Lahan,” Bandung Jur. Tek. Planol. (1985).

[7] Peraturan Menteri ATR/BPN Nomor 12 Tahun 2019 tentang Konsolidasi Tahan. Indonesia, (2019).

[8] J. Coelho, J. Portela, and P. A. Pinto, "A Social Approach to Land Consolidation Schemes: A Portuguese Case Study: The Valença Project,"

Land use policy, 13, 2, 129-147 (1996).

[9] W. Mulyanti, "Pengaruh Konsolidasi Lahan Perkotaan terhadap Harga Tanah di Ringintelu, Kelurahan Kalipancur-Kota Semarang," J. Pembang. Wil. Kota, 11, 1, 63-75 (2015).

[10] M. Louwsma et al., "Land Consolidation and Land Readjustment for Sustainable Development--the Issues to Be Addressed," in Proceedings of the FIG Working Week (2017).

[11] N. D. Talkurputra, "Kebijaksanaan Pembangunan Pertanahan dan Peranan Konsolidasi Tanah," in Lokakarya Konsolidasi Tanah Perkotaan. Kerja Sama BPN dan ITB, (1997).

[12] M. A. Siregar and W. Soetjipto, “Analisis Kesediaan Masyarakat Menerima Program Konsolidasi Tanah Perkotaan Pada Kawasan Permukiman Kumuh Berat," J. Aspir., 4, 2, 101-117 (2013).

[13] B. H. Tedjo and D. Wardaya, "Kajian Potensi Konsolidasi Tanah: Pemetaan Partisipasi Pada Kawasan Kumuh Bantaran Sungai Kahayan," in SMART: Seminar on Architecture Research and Technology, 4, 1, 41-53 (2019). 